\title{
Bioactive Compounds from Marine-Derived Aspergillus, Penicillium, Talaromyces and Trichoderma Species
}

\author{
Rosario Nicoletti $^{1, *,+(\mathbb{D})}$ and Francesco Vinale ${ }^{2}$ (D) \\ 1 Council for Agricultural Research and Agricultural Economy Analysis, OFA Research Centre, \\ 81100 Caserta, Italy \\ 2 Institute for Sustainable Plant Protection, National Research Council, 80055 Portici (NA), Italy; \\ francesco.vinale@ipsp.cnr.it \\ * Correspondence: rosario.nicoletti@crea.gov.it; Tel.: +39-081-253-9199 \\ † Current address: Department of Agriculture, University of Naples 'Federico II', 80055 Portici, Italy.
}

Received: 19 October 2018; Accepted: 24 October 2018; Published: 26 October 2018

The impact of bioactive compounds from natural sources on human life, particularly in pharmacology and biotechnology, has challenged the scientific community to explore new environmental contexts and the associated microbial diversity. As the largest frontier in biological discovery, the sea represents one of the most conducive reservoirs of organisms producing secondary metabolites with interesting biological activities. In the last decades fungi have received increasing attention, both for their pervasive occurrence in several habitats and for their widespread aptitude to develop symbiotic associations with higher organisms. In many cases, fungal strains have been reported as the real producers of drugs that were previously ascribed to marine plants and animals $[1,2]$.

Species of the genera Aspergillus, Penicillium, Talaromyces and Trichoderma are renowned producers of bioactive compounds [3-5]. Until recently they were considered as 'terrestrial' fungi with merely accidental discoveries in marine environments. However, recent findings have demonstrated that actually they are very abundant in marine environments and sometimes establish symbiotic interactions with higher organisms (e.g., the case of Aspergillus sydowii on gorgonians [6]). It can be assumed that many species belonging to these genera of Ascomycetes are rather eclectic in their ability to adapt and thrive in very different environmental conditions. Thus, at least in terms of species number, Aspergillus and Penicillium respectively represent the first and the second most abundant genera of filamentous fungi reported from marine contexts [4,7].

Papers included in this special issue deal with marine-derived species of Aspergillus, Penicillium, Talaromyces and Trichoderma, providing a good overview of their biosynthetic potential. New compounds have been isolated and characterized from strains of A. candidus [8], A. clavatus [9], A. tritici [10], P. raistrickii [11], and Talaromyces purpurogenus [12]. Two papers report the recovery of strains of Aspergillus and Penicillium [13,14] that could not be ascribed to known species, thus underlying that new findings from the marine environment can expand the current taxonomic diversity and eventually contribute to a more coherent classification. Moreover, data concerning several known fungal compounds were discussed, providing clues for a better comprehension of their biosynthetic processes, and a useful indication for chemotaxonomy. Taxonomic implications and their relevance for a correct integration of new data in the current knowledge have been also discussed in a review on mangliculous strains of Talaromyces, after the recent separation of this genus from Penicillium [15].

Several novel compounds characterized from the culture filtrates of these fungi present some original or uncommon structures, such as: the raistrickiones, that represent the first case of 3,5-dihydroxy-4-methylbenzoyl derivatives of natural products [11]; the indole-diterpene alkaloids 
asperindoles $C$ and $D$, containing a 2-hydroxyisobutyric acid residue [13]; 9,10-diolhinokiic acid, which is the first thujopsene-type sesquiterpenoid containing a 9,10-diol moiety, and roussoellol C containing a novel tetracyclic fusicoccane framework [12].

Significantly, most of the above compounds displayed biological activity as radical-scavengers [11], inhibitors of isocitrate dehydrogenase [14], antibiotic and/or cytotoxic agents. Antibiosis ranged from the antifungal activity of the coumarin, chromone, and sterone derivatives produced by A. clavatus R7 [9], to the antibacterial effects exhibited by several compounds towards methicillin-resistant strains of Staphylococcus aureus, vancomycin-resistant strains of Enterococcus faecalis, and Vibrio spp. [8,10]. The assays carried out on several human tumor cell lines were indicative of general antiproliferative effects $[8,10,12-14]$. In the case of penitrem $A$, a previously known mycotoxin, a potential for its use in cancer therapy was disclosed, based on the BK channel affinity and other side effects, which characterize this product as a possible novel sensitizing and chemotherapeutic synergizing agent [16].

In conclusion, we are grateful to all authors who contributed to our Special Issue, in the expectation that at least part of their work may have a follow up with new and exciting discoveries.

Conflicts of Interest: The authors declare no conflict of interest.

\section{References}

1. König, G.M.; Kehraus, S.; Seibert, S.F.; Abdel-Lateff, A.; Müller, D. Natural products from marine organisms and their associated microbes. ChemBioChem 2006, 7, 229-238. [CrossRef] [PubMed]

2. Thomas, T.R.A.; Kavlekar, D.P.; LokaBharathi, P.A. Marine drugs from sponge-microbe association-A review. Mar. Drugs 2010, 8, 1417-1468. [CrossRef] [PubMed]

3. Vinale, F.; Sivasithamparam, K.; Ghisalberti, E.L.; Marra, R.; Woo, S.L.; Lorito, M. Trichoderma-plant-pathogen interactions. Soil Biol. Biochem. 2008, 40, 1-10. [CrossRef]

4. Nicoletti, R.; Trincone, A. Bioactive compounds produced by strains of Penicillium and Talaromyces of marine origin. Mar. Drugs 2016, 14, 37. [CrossRef] [PubMed]

5. Vadlapudi, V.; Borah, N.; Yellusani, K.R.; Gade, S.; Reddy, P.; Rajamanikyam, M.; Vempati, L.N.S.; Gubbala, S.P.; Chopra, P.; Upadhyayula, S.M.; et al. Aspergillus secondary metabolite database, a resource to understand the secondary metabolome of Aspergillus genus. Sci. Rep. 2017, 7, 7325. [CrossRef] [PubMed]

6. Toledo-Hernández, C.; Zuluaga-Montero, A.; Bones-González, A.; Rodriguez, J.A.; Sabat, A.M.; Bayman, P. Fungi in healthy and diseased sea fans (Gorgonia ventalina): Is Aspergillus sydowii always the pathogen? Coral Reefs 2008, 27, 707-714. [CrossRef]

7. Jones, E.G.; Suetrong, S.; Sakayaroj, J.; Bahkali, A.H.; Abdel-Wahab, M.A.; Boekhout, T.; Pang, K.L. Classification of marine Ascomycota, Basidiomycota, Blastocladiomycota and Chytridiomycota. Fungal Diver. 2015, 73, 1-72. [CrossRef]

8. Buttachon, S.; Ramos, A.A.; Inácio, Â.; Dethoup, T.; Gales, L.; Lee, M.; Costa, P.M.; Silva, A.M.S.; Sekeroglu, N.; Rocha, E.; et al. Bis-indolyl benzenoids, hydroxypyrrolidine derivatives and other constituents from cultures of the marine sponge-associated fungus Aspergillus candidus KUFA0062. Mar. Drugs 2018, 16, 119. [CrossRef] [PubMed]

9. Li, W.; Xiong, P.; Zheng, W.; Zhu, X.; She, Z.; Ding, W.; Li, C. Identification and antifungal activity of compounds from the mangrove endophytic fungus Aspergillus clavatus R7. Mar. Drugs 2017, 15, 259. [CrossRef] [PubMed]

10. Wang, W.; Liao, Y.; Tang, C.; Huang, X.; Luo, Z.; Chen, J.; Cai, P. Cytotoxic and antibacterial compounds from the coral-derived fungus Aspergillus tritici SP2-8-1. Mar. Drugs 2017, 15, 348. [CrossRef] [PubMed]

11. Liu, D.S.; Rong, X.G.; Kang, H.H.; Ma, L.Y.; Hamann, M.; Liu, W.Z. Raistrickiones A-E from a highly productive strain of Penicillium raistrickii generated through thermo change. Mar. Drugs 2018, 16, 213. [CrossRef] [PubMed]

12. Wang, W.; Wan, X.; Liu, J.; Wang, J.; Zhu, H.; Chen, C.; Zhang, Y. Two new terpenoids from Talaromyces purpurogenus. Mar. Drugs 2018, 16, 150. [CrossRef] [PubMed] 
13. Ivanets, E.; Yurchenko, A.; Smetanina, O.; Rasin, A.; Zhuravleva, O.; Pivkin, M.; Popov, R.S.; von Amsberg, G.; Afiyatullov, S.S.; Dyshlovoy, S. Asperindoles A-D and a $p$-terphenyl derivative from the ascidian-derived fungus Aspergillus sp. KMM 4676. Mar. Drugs 2018, 16, 232. [CrossRef] [PubMed]

14. Yang, B.; Sun, W.; Wang, J.; Lin, S.; Li, X.N.; Zhu, H.; Luo, Z.; Xue, Y.; Hu, Z.; Zhang, Y. A new breviane spiroditerpenoid from the marine-derived fungus Penicillium sp. TJ403-1. Mar. Drugs 2018, 16, 110. [CrossRef] [PubMed]

15. Nicoletti, R.; Salvatore, M.M.; Andolfi, A. Secondary metabolites of mangrove-associated strains of Talaromyces. Mar. Drugs 2018, 16, 12. [CrossRef] [PubMed]

16. Goda, A.A.; Siddique, A.B.; Mohyeldin, M.; Ayoub, N.M.; El Sayed, K.A. The maxi-K (BK) channel antagonist penitrem A as a novel breast cancer-targeted therapeutic. Mar. Drugs 2018, 16, 157. [CrossRef] [PubMed]

2018 by the authors. Licensee MDPI, Basel, Switzerland. This article is an open access article distributed under the terms and conditions of the Creative Commons Attribution (CC BY) license (http:// creativecommons.org/licenses/by/4.0/). 